\title{
ТЕЗИТЕ НА НОВИОТ МАТЕРИЈАЛИЗАМ НИЗ ПРИЗМАТА НА ФИЛМСКИТЕ НАРАТИВНИ СТРУКТУРИ
}

\author{
Славица Србиновска \\ Универзитет „Св. Кирил и Методиј“, Скопје \\ srbinovskaas@gmail.com
}

Кој е онтолошкиот статус на наративниот лик на позадината на новиот материјализам? Оваа студија претставува испитување на латентниот хуманизам којшто се крие во концепцијата на наративниот лик. Започнувам со дестабилизацијата на категоријата на човекот којашто е овозможена со активирање на концепцијата за пертурбација на Жил Делез. Исто така, се потпирам на поновите повици за нехумана онтологија и критика во пишувањето на Лорен Берлант и Џејн Бенет и предлагам дека е потребно антикарактеролошко читање на наративот, коешто би можело

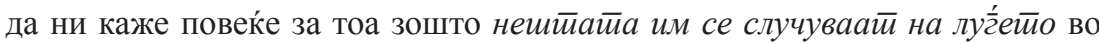
неолибералната матрица на доцниот капитализам.

Клучни зборови: латентен хуманизам, дестабилизација, нехумана онтологија, доцен капитализам 


\title{
THE NEW MATERIALISM: ARGUMENTATION THROUGH THE PRISM OF CINEMATIC NARRATIVE STRUCTURES
}

\author{
Slavica Srbinovska \\ Ss. Cyril and Methodius University, Skopje \\ srbinovskaas@gmail.com
}

What is the ontological status of a character in narrative in the wake of the new materialist turn? This essay presents an examination of the latent humanism at work in the conception of character. I begin with the destabilization of the category of human made possible by Gilles Deleuze's work on perturbation. I also rely on more recent calls for a nonhuman ontology of critique in the work of Lauren Berlant and Jane Bennett, and argue that an anticharacterological reading of a narrative might reveal more about why things happen to people in the neoliberal matrix of late capitalism.

Keywords: latent humanism, destabilization, nonhuman ontology, late capitalism 
Твоето име е Розета. Моето име е Розета. Ти најде работа. Јас најдов работа.Јас имам пријател. Ти имаш пријател. Јас имам нормален живот. Ти нема да пропаднеш низ пукнатините. Јас нема да пропаднам низ пукнатините. Добра ноќ. Добра ноќ.

Розейа (1999), Жан Пјер Дарден и Лук Дарден

\section{1 Неолиберализмот и опресијата}

Оваа студија настојува да ги толкува врските меѓу неколку клучни области кои го детерминираат начинот на кој современата теорија на уметноста ги проучува наративните структури во кои е претставен секојдневниот живот, а кои, во суштината, се структури на репрезентација во кои естетскиот квалитет и обликот во кој тој е реализиран е во тесна врска со политиката и системот во современото општество или со капиталистичката структура на односи на организација на живеењето во ова време во кое човекот им е подреден на предметите. Напорот да се актуализираат содржини кои го претставуваат политичкиот контекст во кој обичниот човек го реализира сопствениот живот низ решетката на сите опресивни механизми на жестоката капиталистичка логика на современиот свет ги толкуваме со преиспитување на остатоците на желбата за живеење на ,добар живот“ во конкретни околности кои ги условуваат сите наши потреби и активности. Ако логиката од која поаѓа оваа студија навистина упатува на „остатоци“ од проекција која во класичната марксистичка доктрина се објаснуваше со утопискиот свет кој треба да го создаде класата која ќе го реализира комунистичкиот поредок со обезбедување на еднаквоста, правдата и братството, денес се чини дека целта е многу далечна и речиси неостварлива. Целокупноста од идеални слики кои беа содржани во проектот за живеењето gобар живой се многу далеку од нивна трансформација во фактичка реалност. Целокупноста од идеални слики денес наликува на пародија на илузиите кои тежнееле да станат реалност. Сепак, оваа желба не е реалистична не затоа што е утописка туку затоа што е уништена под притисокот на системите кои дефинитивно го контаминираат, корумпираат и го деградираат секој обид

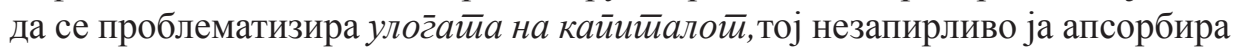
енергијата на човечката, на хуманата егзистенција, ја проблематизира и ја релативизира етиката сфатена како состав од вредности во прилог на живеењето на човекот или на убавината и го исклучува од рамката на идеалите она што се чинело некогашна верзија на патување кон среќата и живот на задоволни луѓе, отворајќи го просторот во кој животот им е подреден на предметите за на крајот и самиот да биде опредметен (Deneen 2018: 85). 
Во пукнатината создадена од препреките, сепак, секој човек се соочува со незапирливиот порив да обезбеди егзистенцијални услови за живот, да сака некого, да има сигурен и праведен систем во којшто живее или да го оствари она коешто концепциски го засега морално-интимниотполитички феномен на живеење добар живот. Во суштината на ваквиот живот, сфатен како проект, како концепција, не станува збор за моќта на човекот самостојно да го оствари тоа туку за емпатија со другиот и за поврзаност која во длабочината на овој феномен содржи фантазија дека во врските со луѓето и нештата може да обликува еден подобар ред, иако често врските упатуваат само на доминацијата на нештата врз луѓето кои се распаѓаaт, а замислениот живот се декомпонира во фрагменти или мигови од потенцијални или краткотрајни поврзувања и задоволства, без можност да имаат траење во животот. Фрагментите на поврзување со другиот човек, ова е можеби и најжестокиот дел од сознанијата на современата теорија на културата, се поттикнуваат интуитивно, а не врз основа на определена педагогија и рационални практики на совладување на знаења во културата.

Системот на вредности, кои се центарот на внимание на концепцијата којашто ја засега интимно-јавната сфера или она што човекот го посакува или има желба да го живее засновано врз љубовта во смисла на неговиот интимен свет и на законот во сферата на јавниот поредок. Ако низата од децении по Втората светска војна содржеа напори за решавање на прашањата за вработувањето, за здравствените институции, за човековите права, за сексуалните, за социјалните политики и дислокациите на класно рамниште, се чини дека тие го изневерија големото очекување на луѓето за демократски живот, а наспроти тоа ја интензивираа депресијата, дисоцијацијата, цинизмот или прагматизмот. Во таа смисла, ги отвораме прашањата за тоа дали фантазиите за добар живот се сѐ уште актуелни. Посуштествен од тоа е фактот дека во центарот на овие размислувања континуирано е отворено прашањето за тоа што значи ga се живее или попроблематичното прашање за тоа како да се одржат очекувањата дека животот ќe добие исполнетост или смисла, а дека економските нестабилности во јавниот простор и непредвидливоста по однос на интимниот живот, во голема мерка обременет со криза, може да се надминат. Телата се забавуваат и пасивноста станува одлика на однесувањето во состојби на силна криза и загуби, она што Жак Рансиер го именува како „дистрибуција на чувствителноста“" не се однесува само на социјалната локација на индивидуата, туку и на прашањата за тоа каква е сигурноста на животот во сегашноста во која се развива и се случува животот (Rancière 2000: 12). Ален Бадју оперира со терминот настиан упатувајќи на будење на свеста, на освестувањето за она што го имаме во таа ситуација, или настан како инструмент за реакција со етички и општествен потенцијал, а 
кој би водел кон промена, меѓутоа притоа не е познато што значи таквиот настан или каква драма и криза може да создаде (Badiou 1988: 279). Патрик Денин ја објаснува таа ситуација поврзана со сегашноста како феномен со висок степен на неопределеност и на несигурност (Deneen 2018: 24). Ова толкување се објаснува со концепцијата за йерйурбащија, воведена од Ж. Делез, или вознемиреност произлезена од актуелноста на т.н. настан, меѓутоа истиот настан онолку колку што поттикнува реакција со цел да обезбеди ослободување на индивидуата со придржување до определени интуитивно воочени норми, сепак, начините и правилата на промени кон кои се тежнее во таквата сийуација или настан не се координирани, тие се хаотични и збунувачки (Deleuze 1968: 108).

Реалноста на нашата современост, а користејќи го овој поим мислам на последните петнаесет до дваесет години, нѐ затвора во состав од настани кои го проблематизираат и го исфрлаат надвор од можност одржувањето на имагинацијата за добар живот. Уметничките жанрови, колку што успеваат низ двојно пропуштање на идејата за „добар живот“, во жанр

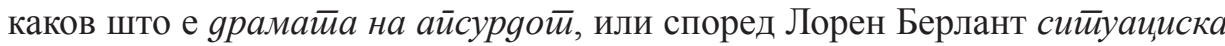
комеguја, во која првостепено сме изложени на имагинарен свет, а потоа на повторна обработка на сликайа за свейойво која се случува соочување со противречности, користат стратегии на презентирање во кои луѓето во еден имагинарен и тривијален поредок стануваат објекти, осудени се на безизлезност која жанрот ја разобличува, а лажниот модел на претставување на задоволство станува проблематичен со оглед на постапката на двојното врамување или двојно фингирање, кое ги прави уочливи слабостите на настанот кој треба да упати на добриот живот, бидејќи тој едноставно не е таков, ниту е претставен со висок степен на неуспех и нестабилност (Berlant 2011: 5). Во епизодите на ситком серијата Да, г̄ocūoguне йремиер (Yes, Prime Minister, 1980-88, 2013), нарацијата за ликовите, кои се истоветни во поголем број вакви жанрови, не се однесува на традиционалните обликувања на комични епизоди за обичните луѓе туку на еден прилично високопозициониран и моќен свет, кој функционира со политичка дистрибуција на норми во општествениот живот, која е суштествена и одлучувачка. Апсурдните и често смешни епизоди во токшоуто на Џон Оливер денес се трансформирана телевизиска верзија на сликата во политичкиот живот каде што жанрот функционира со сложување на нова телевизиска форма сочинета од мозаик на документирани изјави и епизоди од активноста на политичките фигури, најчесто на локално, но и на глобално рамниште, кои се претставени како противречни, апсурдни, гротескни, пародични во сопствените изјави и дејствувања од позиција на моќта, а најмногу од сите овие постапки во нив доминира комичниот ефект. 


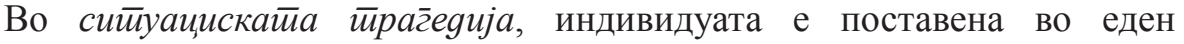
сосема уништен свет од вредности, во свет со нормализирани ситуации на апсурд каде што егзистенцијалните избори се стеснети и подеднакво ризични, а можноста да се остане невин или незафатен од бранот на злото речиси невозможни. Во светот кој е непоправливо уништен и каде што вредносните норми се сосема дестабилизирани апсолутно се проблематизира имагинацијата за еден йоgобар живой или погледот кон таков проект, како и свесноста дека може да се дејствува во име на идејата дека постои можност проектот да постои и да се случи реализацијата на таков живот. Класичната трагедија е наменета за сцената во театарот, овој вид нарација за која се говори низ жанрот ситуациска трагедија се поврзува со медиумот на телевизијата или киното, во неа се надминати последиците кои го ограничуваат трагичниот ефект со негово сведување на емотивна криза поради семејни околности, нарушено пријателство, патетиката на љубовниот однос или т.н. жанр на мелодрама, бидејќи индивидуата во современоста во која го живее својот живот е изложена на несовладливи препреки од емотивен и општествен вид, имено светот е во толкава мерка непоправливо распаднат што овој жанр нема однос кон фантазијата за еден поинаков свет или нема можност да го реализира тоа заради соочувањето со ограничениот состав од доминантно нехумани околности и материјални нешта кои го заробуваат хуманото и вршат опресија врз него.

Суштинска преокупација на оваа студија се современите наративни жанрови кои настојуваат во духот на класичниот неореализам да ја пренесат естетската, уметничката реакција со дело кое проговара за разнишаната субјективност или за нејзината експлозија под притисок на современата општествената криза во опкружувањето исполнето со предмети кои ја потиснуваат, а заради која веќе не се возможни осмислувањата на егзистенцијата низ перспективата на фантазиите за добриот живот продуцирани под влијание на класичната утописка насока која ја даваше марксизмот, потоа притисокот на постиндустрискиот или на доцниот капитализам и либералниот капитализам. Идејата за подобар живот во доцниот капитализам се трансформира во идеја за ирреживување, а тоа значи дека жанрот кој низ уметничка наративна форма настојува да го претстави живеењето под екстремни околности на криза на општествената реалност и криза на хуманото постоење, која, впрочем, опстанокот на човекот го става во центарот на сопствените наративи како предмет, осцилира меѓу документарните (докуфикција) и естетските парадигми на формите кои досега се практикувани. Екстензивноста на кризата во која живееме, загрозувањето на репродукцијата на животот резултира со уметнички вид во кој интензитетот на настанот е претставен во зголемен вид и е моќен да дејствува врз свеста на реципиентот, директно и болно, 
освестувајќи ја безизлезноста, а не фантазијата за иднината.Тоа значи дека современиот човек повеќе не може да биде во центарот на толкувањата во кои е претставен и анализиран како човек, особено толкувањата на сите елементи на кризата произлезена од дејството и притисокот на уништената материја претворена во материја-смет, дејството на парите кои владеат со опстанокот на видот, но и одликите кои го потврдуваат неговиот идентитет на човек. Низ призмата на теоријата за секојдневниот живот, тој може да биде директно претставен во контекст на капиталистичкиот поредок. Во него е сведен на вид кој настојува само да развива вешииини за иреживување, особено ако во светот расте динамиката на инвенција на механизмите за злоупотреба и притисок, а огромното поле на борба за преживување дејствува врз него така што го скаменува, го блокира и го негира неговото постоење како човечко суштество.

Современата теорија за уметноста, фокусирана врз анализата на претставувањето на човекот и на светот денес, веќе не е фокусирана врз притисокот на капитализмот и на неговото доживување како gpecypa/ dressage, за која говори Мишел Фуко, на животот под дејство на нормите, присилната адаптација на тие норми, туку врз светот во кој неолибералните капиталистички ефекти се поврзуваат со висок степен на загрозување на хуманоста, која не само што е фрагментирана, деструирана туку е сосема дезорганизирана и на крајот дехуманизирана (Foucault 2004: 135). Како и да го дефинираме капитализмот, како неолиберален или транснационален феномен,како доцен или постиндустриски капитализам,во него може да се почувствува силната динамика од ритми кои го нормираат, нормализираат или го институционализираат единствено факторот на поседување капитал. Тој е опфатен или е претставен со процеси кои благодарение на развиената технологија го дислоцираат, но тоа не значи дека читањето на уметноста фокусирана врз ирреживувањет̄о како тема се однесува на еднаков и хомогенизиран состав од истоветни ситуации кои ја претставуваат неправдата, туку различните услови и околности кои ја продуцираат, прилагодувањето кон таквите околности добива специфичност и открива одлики развивани низ различните форми кои се слики на борбата за живот (Thrift 2005: 93).

Животот во рамките на секојдневните и обични ритами во денешниот свет динамично и брзо се разорува, зголемениот број на ризици не отвораат простор за очекување на сигурност или на удобност, напротив во него се вложува напор да се совладаат сите притисоци, а по доживеаните трауми се продолжува понатаму, траумата се прифаќа, а посилно од неа станува одржувањето на борбата и опстанокот. Парадоксално е тоа што продолжувањето на оваа борба за опстанок е само по себе трауматичен феномен од човечка гледна точка, меѓутоа таа се одржува како единствена 
активност и смисла во секојдневјето во кое живееме. Состојбата на живеење во криза станува нормална, а не исклучителна,со неа луѓето се справуваат, односно како што своевремено Маркузе укажуваше, луѓето бараат форми со кои се справуваат со кризата и живеат со напрегање за континуирано прескокнување на препреките кои секојдневно се појавуваат, во таа смисла и трауматичниот живот станува состојба која се нормализира во општествените околности, кои се ризични и сурови (Marcuse 2002: 229).

Наративните структури за кои станува збор во оваа студија се однесуваат на индивидуални приказни кои покрај локалното опкружување упатуваат на освестување на состојбите во рамки на кои се живее и глобално, а тоа води делумно кон генерализирани сознанија и толкувања. Уметноста во конкретниов историски момент на живеење нема за цел да ја рафинира нашата чувствителност за новите форми кои се појавуваат во таа сфера, напротив, таа влијае врз подигање, а не рафинирање на чувствителноста на реципиентот по однос на светот и нештата во тој свет кои влијаат врз него. Со помош на таквите форми се претставува или се критикува и се менува реалноста. Она што го доживуваме поврзано со економско-политичките околности и правила дејствува врз чувствата, го запоседнува нашиот внатрешен свет и умот и може да се поврзе колку со функционирањето на институциите, на улицата, на транзициските зони помеѓу границите, националните парадигми, толку и со миграциските ограничувања и стравови, со приватните простори, сето тоа е причина за осмислување на начините на кои луѓето го одржуваат сопствениот дигнитет, настојуваат да останат хумани и да продолжат да ја одржуваат врската со другите луѓе или пак, станува збор за деструирани, дехуманизирани, осамени и уништени субјекти, луѓе.

\section{2 За преживувањето}

Во наративната структура на белгискиот филм Poзет̄a (Rosetta,1999), добитник на наградата „Златна палма“ на Канскиот филмски фестивал, се актуализира состојбата на индивидуата која во современи околности го живее сопственото секојдневие низ настани засновани на преживување. Таа има седумнаесет години и со мајката, која е алкохоличарка, живее во приколки наменети за сиромашно население, имено таа е фокусирана и вклештена во ситуацијата која го дефинира и го исполнува секој ден со смисла ако има работа, а со тоа и елементарни услови за егзистенција, вода, струја, храна. Филмската нарација има епизода која многу критичари ја коментираат, а која се однесува на вечерта во која таа, напуштајќи ја населбата со приколките, решава да се одмори и го посетува местото на 
живеење на момчето кое го запознава како продавач на вафли во уличен киоск. Во симулираната промена на секојдневјето во кое таа се бори со мајката, со нејзиното проституирање и алкохолизам, Розета поминува една вечер кај непознатото момче, вечераат заедно, слушаат касети снимени со музика на групата во која тој некогаш учествувал како тапанар; момчето се обидува дури да танцува со неа, меѓутоа нејзиното тело е неспособно за реакција каква што е опуштањето со музика, таа не умее ниту да танцува, ниту да го промени ставот на телото кое е константно вкочането и напрегнато. Таа несмасно се врти, а момчето повремено се обидува да ја придвижи според ритамот на музиката, макар што во оваа краткотрајна сцена, таа, одвај, учествува и прави напор да се движи и да танцува. Потоа, од необјасниви причини таа бега од местото каде што престојува момчето, меѓутоа се враќа со цел да се одмори од опкружувањето во населбата на социјално сиромашни луѓе и преспива во домот на пријателот. Тоа е остварување на пријателски однос со некого и надминување на океанското чувство на осаменост во кое се нурнува секој ден и живее со напор. Во креветот, таа го изговара монологот кој стои во почетокот на оваа студија, а всушност се однесува на три елементарни нешта, има идентитет, работа, пријател и нормален живот. Таа, во говор кој потсетува на некој вид молитва, вели: „Твоето име е Розета. Моето име е Розета. Ти најде работа. Јас најдов работа. Јас имам пријател. Ти имаш пријател. Јас имам нормален живот. Ти нема да пропаднеш низ пукнатините. Јас нема да пропаднам низ пукнатините. Добра ноќ. Добра ноќ“"

Овие зборови се однесуваат на желбата на Розета која се редуцира на остварување на елементарни егзистенцијални потреби: да има работа и да има пријател. Во апсолутна осаменост и низ монолог, таа, во комуникација со себеси, го соопштува она што е составен дел од социјалниот живот кој таа може да го реализира единствено со зборови упатени кон себеси. Розета, секој ден го минува во постојано движење и со тешка физичка работа, иако е cè уште неполнолетна или адолесцент, тинејџерка. Метафората која може да ја отслика нејзината активност се сведува на незамисливо ограничени и повторливи етапи на акција, честопати проследена со крици, со брзи и одбранбени реакции на претрчување или трчање и тело изградено низ овие активности кои не се својствени за луѓето, туку повеќе прилегаат на она што се прави во некои примордијални фази на развој на човештвото или она што го прават животните. Единствените активности се сведуваат на повторливи дејствија во кои таа ги соблекува чевлите кои обично ги носи пред работодавачите и ги крие во една површинска цевка за одлевање на вода покрај реката, оттаму ги зема гумените чизми и го откопува шишето во кое со жица и бубачка лови риба. Нејзиниот дневен оброк е бесплатната уловена риба од реката. Местото на живеење е приколката која ја дели со 
нејзината мајка, која е алкохоличар и има сексуални односи со сопственикот на населбата за сиромашни луѓе, додека пак Розета е онаа која се грижи за неа, ја плаќа наемнината за приколката, секој ден трча низ градот и бара работа. Минималното остварување на човечките активности во кои таа доживува достоинство, иако се ограничени на секојдневна борба за преживување се оние кои се поврзани со барањето и со наоѓањето работа, а пријателството со Рикет, кој е вработен во киоск со вафли се случува во ситуација во која таа бара работа кај сопственикот на киоскот.

Физичкиот изглед и дневните активности на Розета која е во повеќето повторливи кадри во движење во еден ист амбиент, по улица, низ паркот или во малата шума покрај реката, покрај цевката во која ги крие чевлите и го откопува шишето за лов на риба упатуваат на едноличноста на секојдневниот живот, на празнината на таквиот живот во кој таа не доживува ништо, освен физичка болка во форма на силни грчеви во нозете и во стомакот. Нејзиното суштествување се празни од емоции, останува само страдањето, она што единствено ја смирува е топлиот воздух на фенот со кој го загрева стомакот додека лежи. Розета станува роб на нештата со кои работи и од кои живее, малобројните предмети и храната со чија помош опстанува. Таа живее во осаменост, затоа Розета единствено си припаѓа на себеси, таа нема време, а ниту можност за каков било вид на социјален живот, никаква комуникација надвор од преговарањата за работа и исклучувањата проследени со нејзино гневно реагирање, извици и туркања, проверка на пораките поврзани со конкурси за работа и нормализирање на ситуацијата кога постои ангажман и кога се има работа, нејзиното живеење не може да се разбере ни да се именува поинаку, освен како злоупотреба на детскиот труд. Во работата која ја добива од сопственикот на киосци за вафли, таа крева вреќа од 100 килограми и ја истура во голема мелница за тесто од кое се прават вафлите. Во целина, животот на Розета, малата тинејџерка од сиромашната населба со приколки, е редуциран на извршување на физичка работа по која чувствува болни грчеви. По напорните активности,таа, сепак, успева да преживее. Единствена промена во тој еднодимензионален живот се случува кога го запознава Рикет, момчето кое работи во киоскот за вафли. Местото каде што тој живее дава можност за промена, таа го означува како местио за йрестиој.

Сите закони за правата на граѓаните пропишуваат право на работа, да се биде граѓанин на една држава подразбира негово легитимирање преку партиципирање во продуктивните активности, во работа поврзана со развој на општеството, но и во консумирањето на резултатите од тие активности. Сепак, Розета во сопствениот монолог укажува на йроиейийе или ирразнинииее во кои се надева дека нема да пропадне, имено нејзиното граѓанско право на работа не подразбира сигурна работа. Чувството на 
социјална сигурност и интегрираност во општеството е нарушено, имено наместо сигурност доминираат чувствата на исцрпеност и страв, нејзината борба не е еквивалент на живот во општество со остварување на правата пропишани со законите за право на работа и на сигурен живот. Токму тоа е причината заради која голем број луѓе постојат како тиовар на општеството, надвор од него, тие постојат заглавени сред големото море од отпадни материјали или смет меѓу кои бараат парче облека, пластика или храна, а на крајот и самите се преточуваат во изобилството од непотребни, абјектни фигури, во смет (Bennett 2015: 223). Авторите на наративната структура говорат дека станува збор за филм за „борбата“ каде што овој поим овде се однесува на секојдневната борба за досегање на елементарните нешта, храната и водата. Одеднаш, тие нешта, колку и да изгледа опредметен таквиот живот, суштествено го определуваат.

Почетокот на филмот е влез сред приказната во која камерата го следи грбот на лицето кое е во движење, таа го следи девојчето со користење на техниката на т.н. ирикачување на објективот за грбот на тело во забрзано и нервозно бегство. Подоцна сфаќаме дека станува збор за отпуштање од работа, односно за отпуштање од едно од многубројните малку платени работни места со еднолични и многу ограничени вештини,чие практикување го затапува умот и физички го исцрпува телото. Девојчето го следат двајца крупни мажи од обезбедувањето кои буквално ја исфрлаат од работа. Почетната сцена е исполнета со напнатост предизвикана од турканицата и хаосот настанат со прекинот на работата или отпуштањето со кое таа се справува со агресивно и неконтролирано трчање кон надвор, па дури и со напор да им избега на одговорните лица кои ја прогонуваат, а кои настојуваат и буквално да ја извлечат надвор од фабриката. Со оглед на ефектот кој го предизвикува залепената камера за грбот или за задниот дел од телото на протагонистката во движење, ефектот на хаотичност,кој е соодветно технички изведен бидејќи камерата континуирано се поместува и не е стабилна, се пренесува слика со многу конфузно и невешто снимени делови од тела и постојано треперење. Сликата трепери буквално, таа го следи и го репродуцира движењето на телото, трчањето, криењето, зграпчувањето, растргнувањето и неговото исфрлање. Потоа се повторува вообичаениот ритуал на враќање дома, преку улицата која е во сообраќаен метеж, а потоа преку полето или шумата, преку паркот до цевката во која ги остава чевлите, а потоа до оградата каде што го крева исеченото парче жица специјално обработено како таен влез во населбата на сиромашното население.

Цената која Розета ја плаќа со оглед на околностите во кои преживува се состои во живеење под постојана психичката напнатост, повремено се појавува и бес, агресивност која се манифестира тогаш кога е отпуштена 
од работа, меѓутоа и тоа станува прифатлив составен дел од секојдневниот живот, имено несигурноста. Меѓу многубројните работници, таа е една од оние кои се прекубројни и треба да се отпуштат. Оваа ситуација на отпуштања и трпење на физички болки на кои е изложена од рана возраст заради тешката и исцрпувачка работа, заради ограничувањата во исхраната и заради низа други околности влијае врз нејзиниот развој и создава блокада во хуманиот тек на развојот на личноста. Она што Розета го работи дома, заедно со мајката, е шиењето облека која ја продава во продавници за евтини пари, меѓутоа таа сака работа која би значела интеграција во големото тело на работници, институционализирање на нејзиниот статус и подигање на нејзиното чувство и сознание за себе како за корисен граѓанин кој ѝ припаѓа на заедницата. Како резултат на таквиот статус кон кој тежнее, таа може да го оствари стабилизирањето на нејзиниот економски, а со тоа и на егзистенцијалниот статус. Во моментот кога се вработува во пекарницата каде што ги изработуваат вафлите, таа се менува, имено во монологот, во живеалиштето на Рикет, за прв пат во говорот кон себеси, бидејќи единствено таа на себе си е соговорник и поткрепа, вели дека има работа и чувствува дека има „нормален живот“. Во моментот кога е истуркана или отпуштена од работното место во сцената од почетокот на филмот, таа заминува дома, а потоа го посетува бирото за вработување каде што прашува за работа, но она што ѝ се нуди е само социјална помош која ја одбива, имено таа сака gа рабойи како нормален човек. Таа нормалност на живеењето ја доживува тогаш кога е вработена од сопственикот на киосците за вафли. Имагинацијата за добар животи, како што, впрочем, себеси си посакува gобра ноќ, таа ја живее со остварување на врската со армијата на вработените, односно со одделување на место за себе во светот во кој посакува нормално да живее. Чувството на анксиозност се повлекува пред чувството на задоволство кое се појавува кога таа,конечно, ќе биде вработена, а со тоа ќе почувствува сигурност и припадност кон светот на луѓето кои работат. Какво е тоа задоволство и каков е тој свет во кој човечките битија ја нормализираат состојбата во која се експлоатирани, имено редуцирано живеат, повторливо и еднолично го пополнуваат секој ден со ист состав на активности и редуцирано се хранат, преживуваат?!

Филмската нарација го трансферира чувството поврзано со добивање работа во доживување на утописки чин, на среќа, иако Розета не е вработена вистински или не станува човек кој излегува од системот на бирократските списи на невработените, туку работи привремено. Застрашувачките пукнатини се прескокнати во состојбата во која оној кој е поставен на последната егзистенцијална скала добива можност да работи, иако таа работа е автоматизирано дејствување и го вклучува само искористувањето на физичката сила. Можноста за градење на нормален живот, а тоа значи 
живот во кој си вработен,е доминантна аспирација која го условува доживувањето на Розета дека по вработувањето може ga се оgмори.

Во филмската нарација на делото кое браќата Дарден го создаваат пред филмот Розейа под наслов Beйување (La Promesse, 1996) се влегува во еквивалентна ситуација како онаа во која се наоѓа и Розета, имено тинејџерот Игор во моментот кога е вработен, и со тоа инкорпориран на широката платформа на хиперексплоатација, тој доживува задоволство, а не душевна болка. Тој е испратен да учи автомеханичарски занает во една работилница, меѓутоа неговиот татко го ангажира во својата работа и тој е отпуштен од автомеханичарската работилница. Она што останува да го работи со неговиот татко Роџер се сведува на фалсификување на документи за имигранти, нивно вселување во стара и руинирана куќа, континуирано уценување на имигрантите со неопходната документација за граѓански статус, нивно принудување да работат на изградба на таа куќа во која во исто време се вселени како станари и плаќаат наемнина. Роџер, таткото на Игор, е измамник кој бесконечно го растегнува времето за обезбедување на документација, а притоа постојано бара од вселените станари,кои се наоѓаат во безизлезна ситуација,нови наемнини. Станува збор за затворен круг на злоупотреба, нивно искористување во работата на реновирање на куќата за многу мала компензација, потоа задолжувањето со наемнини кои се намножуваат, каде и супстандардните услови на живеење даваат слика во зголемен формат на оние кои стојат на самото дно на животот. Случајниот настан поврзан со паѓањето на еден од имигрантите, односно со паѓањето на Амиду од скелето го отвора големото прашање со кое драматичните однесувања земаат силен замав. Стравот на Роџер, таткото на Игор, да го пренесе повредениот имигрант во болница би довел до разобличување на неговите постапки засновани на измама,заради тие причини, тој решава да го закопа имигрантот во темелите на куќата, а во таа ситуација сведок и соучесник станува неговиот син Игор. Единствен момент кој ќе влијае врз промената во однесувањето на Игор, и тоа инстиктивно и чувствително, е ветувањето кое ранетиот го бара од Игор. Пред смртта, Амиду му упатува молба на Игор да му вети дека ќе се грижи за неговата сопруга Асита и за неговиот штотуку роден син. Оваа епизода суштински ке ги трансформира однесувањето и чувствата на Игор кон имигрантите.

Општеството во кое живее Игор, како и на глобално ниво, се карактеризира со нормирање на негативното однесување кон имигрантите како луѓе кои немаат статус, тие не се обележани како граѓани, тие се група на индивидуи максимално изложени на злоупотреба, тие се корисни само како евтин работен труд. Имигрантите се во ситуација на апсолутно исклучени индивидуи, тие се едноставно тела кои мигрираат меѓу просторите без заштита и без услови за живот, смртта на овие луѓе не се регистрира во 
општествениот систем, тие се едноставно илегално присуство чиј живот е безвреден. Тинејџерот Игор се обидува да го исполни ветувањето, имено ја извлекува Асита, сопругата на Амид од измамата на Роџер, кој настојува да ја продаде како проститутка, да профитира од неа и во исто време и на таков начин да се ослободи од неа. Сочувството со другиот, особено имигрантот не постои сѐ до епизодата на ветувањето со која Игор се менува. Несреќата на имигрантот, за таткото на Игор, претставува товар од кој сака само да се ослободи, без оглед на фактот дека имигрантот Амид е само повреден, Роџер не размислува за него како за човек чиј живот има вредност кога го закопува жив во темелите на куќата. Потоа, тој настојува да се ослободи од семејството на Амид, односно сака да ја продаде неговата сопруга.

Овие ситуации укажуваат на тоа дека западниот маргинализиран граѓанин опстанува и со исцрпување на други, туѓи тела, особено на оние кои на хиерархиската скала се во состојба на апсолутна потчинетост, нивниот живот е речиси безвреден, тие се на самото дно на егзистенцијата, немаат легален национален идентитет во земјата во која мигрирале илегално, подложени се на притисок и од нив се бараат нови миграции, немаат работа, а ниту извори на егзистенција, живеалиште или храна, тие не се вклопуваат во ниту еден сегмент од светот во кој присуствуваат. Игор ја заштитува Асита сместувајќи ја во друг простор, тој ѝ дава пари и ја упатува побрзо да замине подалеку од Роџер, имплицирајќи со тоа дека неговиот татко е опасност за неа. Обидот да ја спаси Асита е исполнување на ветувањето на Игор кон Амид, меѓуута не е сцена во која тој ги разобличува фактите, имено дека сопругот на Асита е мртов. Оваа сцена открива сосема спротивно и речиси неосвестено, но интуитивно реагирање на Игор, кој ја напушта педагогијата на Роџер, на неговиот татко, која упатува на искористување, себезадоволување, ослободување од препреките по секоја цена, живеење без одговорности кон другиот, особено ако тој е само тело кое може да се злоупотреби и преку него да се заработи, ако тој живее необележано, надвор од системот, без права. Засолништето на Асита е живеалиштето во кое престојувал Игор додека работел и го учел механичарскиот занает во гаражата. Обврската која ја презема Игор за Асита и нејзиниот живот, како и за животот на нејзиното дете е сосема нова димензија во целокупниот след од настани, станува збор за епизода која за Игор не е сосема осмислена, ниту пак соодветна на однесувањата кои ги практикува врз основа на она што го учи во животот со Роџер како негов татко, суровоста, немилосрдноста кон другиот во замена за лесна заработувачка. Предмет на хиперексплоатација и лесна дисквалификација се заменливите тела на оние кои се без заштита, особено жените и децата, тие се изложени во свет во кој најлесно се елиминира таквиот живот, бидејќи тој со сопственото нелегално присуство веќе ги нарушил правилата и постои надвор од контролите на системот. 
Во вознемиреното однесување на Игор, примарно заради ризикот и отстапувањата од пропишаните правила за дејствување според „педагогијата“" на неговиот татко, Асита се вклопува како рационална фигура, таа, иако ги практикува искуствата поврзани со суеверно реагирање на знаците, што е аналогно на африканската култура од која доаѓа, го освестува чинот на преселба во новото засолниште како проблем, таа упорно тврди дека знае и глеgа во извлечените и расечени внатрешни органи на петелот дека нејзиниот сопруг е тука, таа настојува да му се спротивстави на Игор, имено му се заканува со нож во моментот кога тој очекува благодарност. Признавајќи ѝ за тоа каков живот за неа испланирал Роџер, тој смета на нејзина позитивна реакција, потоа смета на тоа дека ќе биде прифатен, а не дека ќе биде изложен на закани и бунтувања. Сепак, на крајот од сцената, тој неочекувано ја прегрнува, со тоа ја збунува, но на извесен начин успева да ја смири. Со прегрнувањето на Асита, Игор се обидува да добие од неа повратна реакција за сѐ она што го прави за неа, спасувањето од Роџер, обезбедувањето средства за живеење, иако во камуфлирана варијанта и со објаснување дека се тоа пари кои Амиду ги добил додека се коцкал. Тинејџерот и имигрантката во оваа сцена се однесуваат надвор од нормите, тој и Асита се зближуваат како луѓе, иако целата сцена е напната, исполнета со извици и изрази на вознемиреност, а завршена со привидно меѓусебно помирување и усогласување на односите, тоа е сцена на креирана/ изградена наклонетост и може да се оддели како сцена на хуманост, а не на суровост и злоупотреба. Топлата и неочекувана реакција на Игор со прегратка упатува на неговото сочувствување со имигрантката, тоа е сцена која укажува дека тоа е посакуван однос, однос во кој се доживува емпатија со страдањето на другиот, а не однос соодветен на реалноста во која сите преживуваат злоупотребувајќ ги другите. Адолесцентот, припадник на белата раса, развива комуникација со имигрантката, тој во почетокот е само бел експлоататор, меѓутоа со вложувањето во тоа да ја спаси од продажба, потоа во следните етапи кога ѝ обезбедува услови за живеење, загревање на просторијата каде што таа престојува со бебето, но и пари во форма на вратен долг од Амиду, се трансформира. Во тој однос, од точката во која сѐ започнува со напрегнатост и недоверливост, лутина и одбивање како да станува збор за непријатели се доаѓа до точка на меѓусебно поврзување и реципрочно изградена доверба, а тоа значи дека оддалечените светови на осамениот Игор и уште понесреќната Асита се вкрстуваат. Тој, по сцената со прегратката, излегува надвор, се повлекува во еден агол и се оgморана начин на кој тоа го прави Розета во домота на Рикет, а притоа плаче, колку заради сопствениот ограничен и корумпиран живот и лаги толку и заради потребата повторно да направи гест на добро однесување и да манифестира грижа за Асита. Таа состојба е сосема ново доживување за него, тоа чувство 
на задоволство да се грижи за оној кој се наоѓа во безизлезна ситуација за него е извор на среќа, тој себеси се реализира како човек, како маж, а не како корумпиран човек и лажливец (Braidotti 2010: 201).

Во световите на двајцата тинејџери, на Розета и Игор, авторите вградуваат сцена во која ликовите, без позадина од која можат да го научат автентичното однесувањето и комуникацијата од социјален карактер, постапуваат со чувства на емпатија кон другиот и сметаат дека тоа е начинот на кој овој свет би можел да стане простор за добар живот,иако, според возраста, тие не се способни да реагираат рационално, туку тоа го прават интуитивно.

Розета има родител алкохоличар, сексуално промискуитетна личност, а Игор како модел наспроти себе има родител кој злоупотребува, фалсификува и лаже. Ниту едниот, ниту другиот не го прифаќаат родителскиот модел на живеење како основа на желбата за градење на иден добар живот, напротив, тие живеат со желба да формираат општествена комуникација, пријателство, хуманост, сочувство за другиот. Тоа се состојби кои дефинитивно ги обезбедуваат и кои се проследени со задоволство произлезено од присуството на другиот што го поништува чувствувањето на осаменоста и анксиозноста, отуѓеноста и дехуманизираноста. Нивните епизоди на хуманост се опкружени со многу насилство и со исцрпувања во светот онаков каков што е околу нив, таткото го тепа Игор, Розета се бори со алкохолизираното тело на мајката, ја покрива, ја одвраќа од сексуалните односи со сопственикот на населбата за приколки за сиромашно население. Овие куси епизоди соодветствуваат на состојби на дејствување на деца кои не можат да го рационализираат своето однесување, тие се импулсивни, покажуваат гест на пријателство и учествуваат во култивирање на светот според правилата кои не ги познаваат, но во сопствената економија на чувства имаат простор за доживување на среќа кога помагаат или кога се дружат и имаат работа. Тоа, според нив, но и според околностите кои ги формираат како луѓе, се доживувања за тоа дека живеат нормален живой.

Капиталистичкиот поредок кој ветува живот за оној кој вложува труд и работи, во конкретниве приказни го актуализира безмилосното исклучување на истиот, на младиот човек од животните практики на образование, на работа и надомест за вложениот труд, од дом, од љубов и сигурност и го остава на економското дно каде што умираат сите имагинарни проекти за иднината и за животот. Онолку колку што длабоко долу се поставени ликовите по вертикалата или хиерархиската скала на капиталистичкиот поредок, на доцниот неолиберализам, толку се тие надвор од можностите за вклопување во општеството, во колективните активности, а нивниот живот е хаотичен состав од неуспеси, разочарувања и огромна осаменост. Во таквите околности, тие не развиваат однос кон виталните и одржливи концепции и репродукција на животот, негово продолжување, ја става Розета 
пред искушението да посегне по својот живот, да го предаде пријателот за да го заземе неговото работно место во општество во кое вредностите се релативизирани, каде што вработувањето, и покрај уредноста и успешноста, трае само три дена, каде што брзо се случува отпуштање од работа, каде што измамата и злоупотребата се средство за одржување на егзистенцијата, а идејата за иднина или замислата за иднината е избришана и од меморијата. Креативниот дух на младите луѓе кој светнува и дејствува во куси епизоди од нивните маргинални животи е исцрпен, се чини дека е исцрпена и нивната енергија за живеење. Розета на крајот го отпушта плинот во тесниот простор на приколката откако го поставува полуживото тело на нејзината мајка во алкохолизирана состојба во креветот. Зема едно од четирите сварени јајца и додека го јаде во креветот сфаќа дека плинската боца е испразнета и тргнува по нова боца која ја носи со напор. Патеката на нејзиното измачување на крајот од филмот, кога ја напушта работата стекната со предавство на пријателот кој го мами газдата, е слика на тело кое се движи со тешкотија, носи преголем товар, иако тоа е тело на дете, девојче. Розета, физички, одвај успева да го изоди патот по чија должина ја носи тешката плинска боца. Предметот е претежок за нејзиното детско тело, но таа издржува, паѓa со боцата и се крева. Рикет ја следи, сликата е дополнително напната, затоа што како семантичко дополнување во кадарот/ сликата се вклопува и продорниот звук на моторот кој го вози Рикет. Тој настојува да ја заплаши и ѝ се заканува заради направеното предавство, но на самиот крај, таа ја спушта плинската боца и за прв пат плаче излевајќи ја болката произлезена од страдањето кое низ целиот филмски наратив ни е прикажано дека го носи без да воздивне. Таа последна слика покажува дека за првпат под притисокот на животот кој тече без изгледи за промена, ова девојче се обраќа некому, таа својот поглед го вперува кон Рикет кој ја крева од земја. Нејзиниот поглед изразува очај и депримираност под притисок на товарот кој ја уништува и исцрпува, ја истрошува и ја измачува.

Во двата филма, браќата Дарден се концентрираат на ликови на млади луѓe, речиси деца, кои се припадници на самото дно на белата работничка класа, покрај нив се појавуваат и ликовите на имигрантите, оние кои се без идентитет и кои живеат во континуирана потрага по место и работа. Воспоставената институција на зближување и доживување на блискост со оној кој е подеднакво исклучен од општествената заедница поттикната од странични и случајни околности станува основа за обликување на жанр кој дејствува директно со својата повратна или репаративна логика, која му дозволува на гледачот да спознае дека постојат исклучоци и доживување на среќa надвор од економските, политичките и социјалните вмрежувања во просторите на легалните институции. Документарната слика транспонирана со играните филмовите на браќата Дарден ја разобличува неолибералната 
реалност на празните и очајни луѓе, како што се родителите на Розета и Игор, која децата истовремено ја гледаат, но и ја живеат. Тие не познаваат други можности за излез, освен секојдневните исцрпувања во измами и безнадежна потрага по работа. Затоа и двајцата уживаат во кусите епизоди на манифестација на човечноста, различна од дехуманизираната, нечовечка средина и секојдневица.

Логиката на наративните структури е основа за градење на сликата за општественото предавство и структурната потчинетост во доменот на етиката, економијата и политиката за правата на човекот. Односите меѓу родителите и децата се длабоко нарушени, Розета се грижи за сопствената мајка како мајката да е дете, Роџер се дружи со синот и го интегрира во општеството и работата како работник, како човек рамен на себе, тој дури со споделување на прстените и со тетовирањето настојува со синот да оствари братско дружење, тој со него пие и се дружи во кафеана со други жени, меѓутоа во тие сцени Игор е навистина оптоварен од несоодветноста на она што го прави, имено тој е само прерано созреан адолесцент кого сликата на момче кое пуши цигара и прегрнува возрасна жена само го претставува

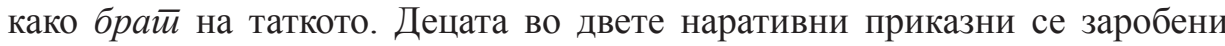
во животни текови без изгледи за излез, затоа тие немаат никакви илузии за добар живот, тие се робови на сиромашниот живот во кој се родени и заглавени. Таквиот живот во рамки на неолибералната капиталистичка економија добива карактеристики на бескрајно осамен и празен живот. Тоа е живот кој го водат многу бели работнички семејства или имигрантски групи на нелегално пристигнати доселеници, тој, во таква форма се нормализира, станува едноличен и банален, а не исклучителен, тоа е живот во криза која алармира. Sвоното за аларм одsвонува во сите општествени институции и ја означува потребата за решавање на овие состојби.

Придвижувањето кон некоја промена во документарните стратегии на раскажување за животот на белата работничка класа, особено за децата припадници на таа класа, во филмовите на браќата Дарден не се забележува. Во нив нема штрајкови, бунтови, протести и револуции. Единствено, функционална компонента во насока на различно поведение во овие структури е спознанието до кое доаѓаат двајцата адолесценти, а тоа е дека тие сакаат или копнеат да остварат нормален живот. Се чини дека во таа самоосвестена желба лежи моќта на луѓето кои во рамките на еднодимензионално нормираната егзистенција во неолибералниот поредок во криза вршат притисок со сопственото присуство, а нив ги има сѐ повеќе, тоа значи дека притисокот станува сѐ посилен (Pfeifer 2015: 26).

Поимањето на т.н. нормален живо $\bar{u}$ се вклопува во времето во кое имањето работа, без оглед на експлоатацијата, кај индивидуата предизвикува чувство на вредност и спознание за тоа дека треба да се живее како корисен 
човек. Спротивни доживувања поттикнуваат деновите без работа, тогаш кога се губи работата и се напушта местото кое привремено е добиено, тогаш во масовната пролетерска економска структура се јавува чувство на гнев кој кусо трае, а потоа загосподарува едноличното трагање по нов извор на егзистенција, нешто налик на животинските напрегања да го утврдат, искористат и да го напуштат изворот на вода или храна. Доживувањето на безвредност се развива тогаш кога не постои чувството за тоа дека човекот е дел од една општествена целина, кога не припаѓа, тогаш го губи чувството за вредност, затоа овие наративни структури не го проблематизираат прашањето за експлоатацијата како зло, во тесниот простор за остварување на вредноста, таа се реализира ако се стане припадник на пролетерската економска структура. Поинакви форми на доживување на задоволство се остваруваат при поврзувањето и воспоставувањето на однос со човекот наспроти нас, како што покажува филмската нарација, преку пријателство, меѓусебно дружење и препознавање, преку емпатија. Во такви околности, овие односи ја потиснуваат вредноста и значењето на тоа да се припаѓa на семејство, нација, држава. Имигрантите и луѓето кои немаат работа, оние кои немаат капитал се во истата група, нивните животи се одвиваат во ситуации на преживување, наместо живот поврзан со експлоатираната група на вработените, независно од фактот дали поседуваат документи и припаѓaат на една држава како граѓани, овие групи луѓe го формираат притисокот насочен против силата на капитализмот која безмилосно ги гази и ги уништува телата, ги закопува и ги прескокнува како безвредни и бескорисни, затоа што се многубројни.

Филмската нарација се фокусира и врз епизоди во кои се појавуваат дејствија кои се спротивност на експлоатацијата или измамата, Во

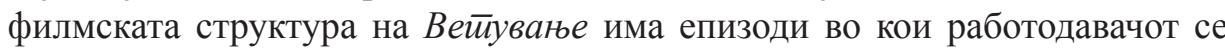
грижи за вработениот, како што тоа во почетокот го прави сопственикот на гаражата каде што работи Игор, кој, пак, во одделни ситуации им дели цигари на имигрантите вселени во куќата, кои се, во исто време, градители на таа куќа, потоа во нарацијата на приказната за Розета има сцени каде што таа ја продава облеката која ја шие нејзината мајка и притоа, сопственичката на бутикот за облека, го истакнува квалитетот на сошиената облека. Други епизоди упатуваат на користење на слободното време кое Игор и неговиот татко го минуваат забавувајќи се во кафеана со караоке настап, додека пак, Розета е поканета и минува една ноќ вечерајќи во домот на новиот пријател Рикет, кој го запознава онаму каде што привремено се вработува. Над целината од овие епизоди се надвиснува моќната капиталистичка машина која ги потиснува сите можни верзии на сива економија, но поттикнува и скриен транспорт на човечки тела и предмети, поттикнува на константно движење и потрага по работа под какви било околности, во привремени 
живеалишта. Сосема спротивни на овие се сцените на бруталност во комуникацијата меѓу децата и родителите, на пример Розета не го прифаќа однесувањето на мајката која купува алкохол со парите кои Розета ѝ ги дава за вода, и која потоа, во замена за пари за алкохол, има сексуален однос со сопственикот на приколките каде што живее со Розета, а Розета ја презира; сите епизоди проследени со напор таа да го реализира нормалниот живот се нарушени од однесувањето на мајката, дури и тогаш кога Розета бара од неа да се лечи од алкохолизмот во државна институција и ѝ ветува машина за шиење во замена за што, во тие конфликтни ситуации, мајката одбива сѐ и ја турнува Розета во реката, а потоа бега. Клучни се и епизодите во кои Розета гневно ги отфрла симулациите на нормален живот како што е приготвениот ручек во приколката, но и засадените цвеќиња пред приколката. Поимањето на нормалниот живот во главата на Розета не се поврзува со просторот на населбата со приколки, таа сака вистински дом и вистински живот. Симулацијата во неа предизвикува чувство на одбивност, бидејќи ја засилува свеста за лагата во реалноста во која живее.

Се чини дека станува јасно колку немилосрдни стануваат околностите во капиталистичкиот систем во кој не само можноста за стекнување работа во која се случува експлоатација е посакувана цел туку и колку таа овозможува релативизирање на вредносниот систем во кој оние кои се на дното, а во тој простор можеби најниско според статусната позиција се поставени имигрантите, иако кон нив се приклучуваат и невработените граѓани, а меѓу нив и адолесцентите како Розета и Игор, таа посакувана цел подразбира делумно доживување на сигурност и припадност кон определена општествено легализирана институција. На крајот согледуваме дека улогите на Розета и Игор се во исто време улоги на возрасни, но и на деца, макар што живеењето на детството или адолесцентскиот период во нивните животи предадени на работата која ја бараат или која аа изведуваат е неостварливо. Системот со релативизирани вредности и измами поттикнува овие млади луѓе наместо да добијат емотивна поддршка во семејството, ги наведува тие самите да измамуваат, и да бидат измамувани. Розета се грижи за својата мајка алкохоличар, со која во исто време се расправа и ја тепа, додека пак Игор ги преживува судирите со таткото кој повремено го напаѓа, потоа бара од него лојалност и го тепа,а на крај од серијата контроверзни акции со имигрантите, таткото му вели дека куќата ќе му припадне на Игор. Тоа за него е приказна која не постои, имено Игор бара да се престане со измамата. Единствениот интимен простор за развивање на емоции во животот на Розета не е само противречното доживување на одговорност за мајката, туку и погледот вперен кон Рикет, како оној кој е во нејзиното опкружување додека таа со огромен напор ја носи боцата со плин и плаче. Игор во последното предупредување кое ѝ го упатува на 
Асита по однос на нужноста да замине за да се спаси од неговиот татко искажува дел од вистината, имено тој објаснува дека Амид е мртов. Со тоа се отвора просторот за нејзиното свртување кон него, за нејзиното останување со него и за неговата грижа за неа. Иако незавршени и сосема неизвесни се односите кои ги развиваат овие адолесценти кон Друг̄иот̄, тие на навистина необјаснив, но моќен начин, во куси епизоди искажуваат потреба за блискост, а тоа не е ништо друго туку потреба за љубов и човечност. Таа потреба е проследена со високиот ризик да бидат одбиени, меѓутоа тие се обидуваат да развијат однос кон странецот, кон туѓинецот како оној кој сакаат да стане и да остане нивни сосед или пријател. Во таа смисла, тие не размислуваат низ нормираните параметри на сексуалните, емотивните и други поврзувања, тие во духот на поместените критериуми и вредности ја прифаќаат вредноста на присуството на другиот кој е сосед, така конструираат фантазма за надминување на осаменоста. Тоа се напори насочени кон движење на животот во насока на напредување коешто ќе создаде од нивните секојдневни егзистенции помалку лош живот од оној во кој се наоѓаат.

\section{Библиографија}

Rancière, J. (2000). Le partage du sensible: Esthétique et politique. Paris: La Fabriqueéditions.

Badiou, A. (1988). L'êtreetl'évenément. Paris: Éditions du Seuil.

Bennett, J. (2015). System and things: On vital materialism and object-oriented philosophy. In R. Grusin (ed.). The nonhuman turn, 223-239. Minneapolis and London: University of Minnesota Press.

Berlant, L. (2011). Cruel optimism. Durham and London: Duke University Press.

Braidotti, R. (2010). The politics of "Life Itself" and new ways of dying. In D. Cooleand and S. Fros (eds.). New materialisms: Ontology, agency and politics, 201-218. Durham and London: Duke University Press.

Foucault, M. (2004). Surveiller et punir: Naissancedela prison. Paris: Copyleft Yuji.

Deleuze, G. (1968). Différence et répétition. Paris: Press Universitaires de France.

Deneen, P. J. (2018). Why liberalism failed. New Haven and London: Yale University Press.

Marcuse, H. (2002). One-dimensional man. London and NewYork: Routledge.

Pfeifer. G. (2015). The new materialism: Althusser, Badiou, Žižek. London and NewYork: Routledge.

Trhrift, N. (2005). Knowing capitalism. London: Sage Publications.

Žižek, S. (2009). Discipline between two freedoms: Madness and habit in German idealism. In G. Markus and S. Žižek (eds.). Mythology, madness, and laughter: Subjectivity in German Idealism, 95-121. NewYork and London: Continuum. 